\title{
Uma historiadora do Império Português
}

No dia 30 de janeiro último perdemos Maria de Fátima da Silva Gouvêa. Ela faleceu subitamente, de embolia pulmonar, quando se preparava para regressar de Lisboa, onde estava há cerca de um ano, realizando atividades de pesquisa, a que era tão devotada.

Sua morte tão repentina e prematura produziu tristeza e perplexidade em todos os que a conheceram e conviveram com ela nos vários ambientes acadêmicos em que circulou no Brasil, Portugal, Inglaterra e EUA.

Fátima ingressou na UFF como aluna, na Graduação em História, no final da década de 70. Depois de uma especialização em História Social na Universidade Federal do Paraná, no início dos anos 80, decidiu continuar sua formação em Londres. Sob a orientação de dois grandes nomes da historiografia, Professores John Lynch e Leslie Betthell, concluiu, em 1984, o Mestrado no Institute of Latin American Studies e, em 1989, o Doutorado no University College of London. Lastreada em pesquisa de fôlego sobre as instituições do Brasil Imperial, Fátima regressou ao Brasil e ingressou na UFF como professora no Departamento de História, em 1991. Logo deu início às atividades na Pós-Graduação e participou da criação do NUPEHC - Núcleo de Pesquisa em História Cultural, do qual foi coordenadora em vários períodos. Ainda nos anos 90, foi convidada a dar aulas no Dikinson College, nos EUA, com bolsa da Fulbright, estabelecendo laços acadêmicos com aquele país, depois renovados por ocasião de seu Pós-Doutorado na Johns Hopkins University, em 2000, sob a supervisão do Professor Russell-Wood.

Em Portugal, suas passagens e contatos foram muitos. Esta sua última estadia se deu através de uma bolsa de Pós-doutorado, no âmbito do convênio CAPES-CRICES, com o projeto A Monarquia e seus Idiomas: corte, governos 
ultramarinos, negociantes, régulos e escravos no mundo português (sécs. XVI-XIX). Fátima também se encontrava como Investigadora Visitante do Instituto de Ciências Sociais, da Universidade de Lisboa, sob a supervisão do Professor Nuno Gonçalo Monteiro, parceiro em inúmeras atividades acadêmicas anteriores.

Pesquisadora 1 do CNPq, participante do projeto PRONEX Culturas Políticas Usos do Passado e pesquisadora recém-premiada pelo programa Cientista do Nosso Estado/FAPERJ, Fátima tornou-se uma das mais destacadas especialistas no âmbito da história moderna e colonial do PPGH. Autora do livro Império das Províncias, fruto ainda inédito de sua pesquisa de Doutorado, ainda up to date neste ano de 2009, quando foi publicado, Fátima foi coorganizadora da obra de referência para a historiografia do Brasil Colonial e do Império Português na Época Moderna, O Antigo Regime nos Trópicos (2001) e do livro Culturas Políticas: ensaios de história cultural, história política e ensino de história (2005), resultado de pesquisas do NUPEHC.

Fátima deixou, ainda em andamento, importante projeto editorial sobre a historiografia do Brasil Colonial, reunindo especialistas na área, do Brasil e do exterior. Com o Professor João Fragoso, organizou importante livro intitulado Na trama das redes: política e negócios no império português, século XVI-XVIII. Fruto do Seminário Internacional organizado por ela na UFF, entre maio e junho de 2006, a obra tem previsão de lançamento para março próximo, pela editora Civilização Brasileira. Entre os anos 2006 e 2007, Fátima foi uma das editoras da Revista Tempo e organizadora do dossiê Trajetórias e sociabilidades no Brasil da Corte Joanina, publicado na Tempo n. ${ }^{\circ} 24$, no primeiro semestre de 2008.

Em cooperação com historiadores brasileiros e portugueses, como Maria Fernanda Baptista Bicalho, João Fragoso, Antônio Carlos Jucá, Nuno Gonçalo Monteiro, António Manuel Hespanha, entre outros, Fátima contribuiu para construir um novo marco historiográfico, ao inserir o que se costumou designar como história do Brasil-colônia na dinâmica do Império Português. Sua dedicação à pesquisa, associada ao dinamismo e entusiasmo invejáveis com que se empenhava na realização de seus projetos, fez dela um importante elo nessa rede de historiadores, entre os dois lados do Atlântico.

Há que se destacar, também, a importância de suas pesquisas para a renovação do ensino de História das Américas, área em que atuava com muito entusiasmo na Graduação, desde 1992, e que fez dela um membro 
atuante da ANPHLAC - Associação Nacional de Pesquisadores em História das Américas.

Orientadora de inúmeras teses e dissertações, Fátima será sempre lembrada pelo carinho e atenção desmedidos que dedicava a seus alunos e orientandos, pelo destemor na defesa das causas que eram suas, pela transparência, generosidade, simpatia e simplicidade que nunca a abandonaram. Sua vibração pelo ofício de historiador era tal que costumava dizer ser a sua a "melhor profissão do mundo".

Essa guerreira de coração imenso partiu de repente e deixou em todos os que a admiravam um sentimento de perda irreparável. Ficamos com o consolo de ter tido o privilégio de compartilhar tantas experiências e conviver com pessoa tão querida e valorosa durante todos esses anos.

Que seu filho Luigi saiba que, além de mãe dedicadíssima e amorosa, Fátima deu sentido à sua existência cultivando saberes e afetos em todos os lugares por onde passou.

NUPEHC/PPGH/GHT

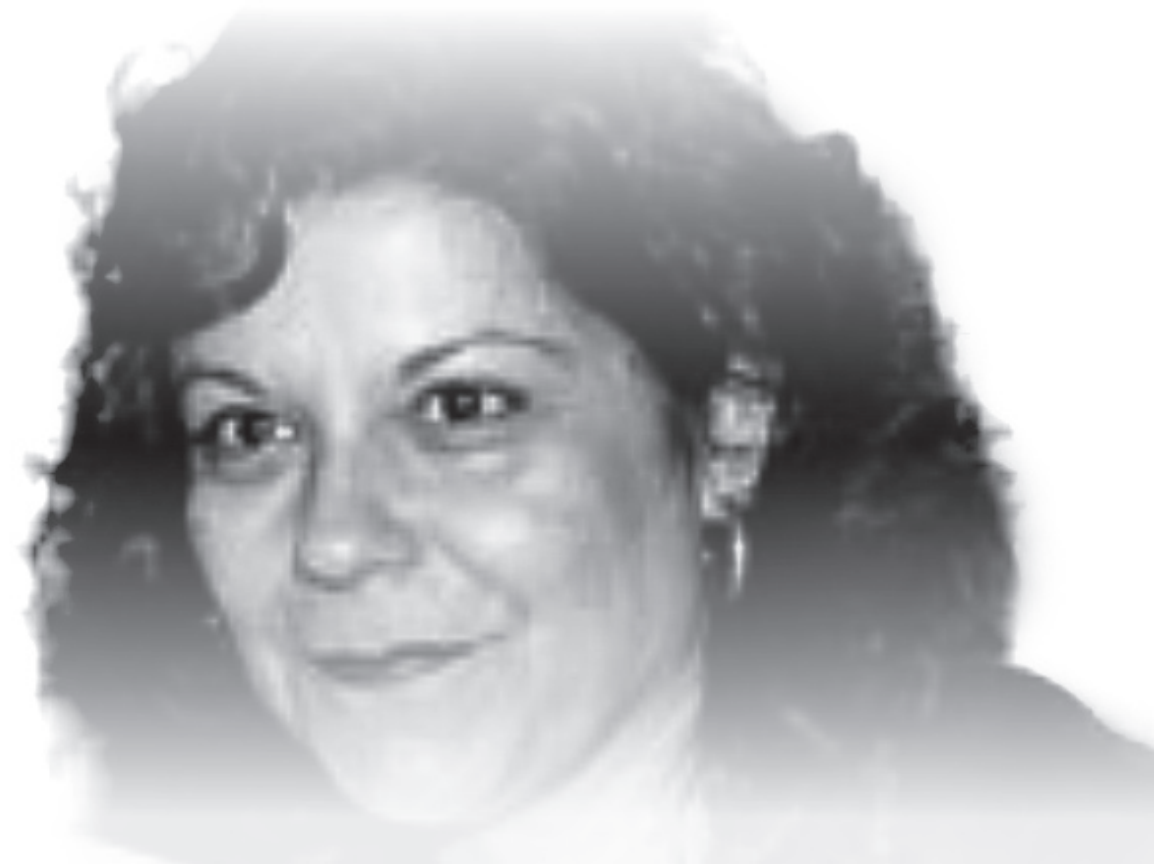

